\title{
Quality of Life Assessment by the Endometriosis Health Profile (EHP-30) Questionnaire Prior to Treatment for Ovarian Endometriosis in Brazilian Women
}

\section{Avaliação da qualidade de vida através do questionário Endometriosis Health Profile (EHP-30) antes do tratamento da endometriose ovariana em mulheres Brasileiras}

\author{
André Vinícius de Assis Florentino ${ }^{10}$ Ana Maria Gomes Pereira ${ }^{1}$ João Alfredo Martins ${ }^{1}$ \\ Reginaldo Guedes Coelho Lopes ${ }^{1}$ Raquel Martins Arruda ${ }^{1}$ \\ ${ }^{1}$ Department of Gynecology, Division of Endometriosis, Hospital do \\ Servidor Público Estadual, São Paulo, SP, Brazil \\ Rev Bras Ginecol Obstet 2019;41:548-554 \\ Address for correspondence André Vinícius de Assis Florentino, MD, \\ Hospital do Servidor Público Estadual, Av. Ibirapuera, 981, \\ Indianópolis, São Paulo, SP 04028-000, Brazil \\ (e-mail: f.andrevinicius@gmail.com).
}

\begin{abstract}
Objective To evaluate the existence of an association between ultrasound findings and epidemiological and clinical factors using results obtained from the EHP-30 questionnaire in women with ovarian endometriosis.

Methods A cross-sectional observational study was performed between July 2012 and May 2015, in which patients with chronic pelvic pain suggestive of endometrioma, as indicated by the results from a transvaginal pelvic ultrasonography, completed the standardized Endometriosis Health Profile - 30 (EHP-30) questionnaire to access quality-of-life scores before beginning treatment for endometriosis. A total of 65 patients were included. The data was analyzed in the statistical program IBM SPSS Statistics for Windows, Version 22.0 (IBM Corp., Armonk, NY, USA) for the comparison of data through linear multiple regression.

Results The suitability of the linear regression model was confirmed by the histogram of the dependent variable and the residue distribution plot, confirming the trend of linearity as well as the homogeneous dispersion of the residues. The mean age of the patients was $39.7 \pm 7.1$ years old. The majority was Caucasian (64.5\%), had completed higher education (56.5\%) and was nulligravida (40.3\%). Infertility was present in $48.4 \%$

Keywords

- endometriosis

- endometrioma

- pelvic pain

- dysmenorrhea

- quality of life of the patients studied. Out of the total sample, $80.6 \%$ of the cases were symptomatic and complained mainly of acyclic pain, $79 \%$ of dysmenorrhea, and $61.3 \%$ of dyspareunia. This reflects the negative influence of endometriosis on the quality of life of patients with this disease.

Conclusion Dyspareunia and acyclic pain were independent factors of correlation with high scores in the EHP-30 questionnaire, reflecting a worse quality of life.
\end{abstract}

DAndré Vinícius de Assis Florentino's ORCID is https://orcid.org/ 0000-0002-8005-3174.

received

January 13, 2019

accepted

May 27, 2019
DOI https://doi.org/

$10.1055 / \mathrm{s}-0039-1693057$ ISSN 0100-7203.
Copyright $\odot 2019$ by Thieme Revinter

Publicações Ltda, Rio de Janeiro, Brazil
License terms

(c) (1) 


\section{Resumo}

\section{Palavras-chave \\ - endometriose \\ - endometrioma \\ - dismenorreia \\ - dor pélvica \\ - qualidade de vida}

Objetivo Avaliar a existência de associação entre os achados ultrassonográficos e os fatores epidemiológicos e clínicos com os resultados obtidos no questionário EHP-30 em mulheres com diagnóstico de endometriose ovariana.

Métodos Realizou-se um estudo observacional transversal entre julho de 2012 e maio de 2015, no qual as pacientes com dor pélvica crônica com imagem sugestiva de endometrioma na ultrassonografia pélvica transvaginal preencheram o questionário padronizado Endometriosis Health Profile - 30 (EHP-30) para acessar os escores de qualidade de vida antes de iniciar qualquer tratamento para a endometriose. Foram incluídas 65 pacientes. Os dados foram analisados no programa estatístico IBM SPSS Statistics for Windows, Versão 22.0 (IBM Corp., Armonk, NY, EUA) para a comparação dos dados através de regressão múltipla linear.

Resultados A adequabilidade do modelo de regressão linear foi confirmada através do histograma da variável dependente e do gráfico de distribuição dos resíduos, confirmando a tendência de linearidade, assim como a dispersão homogênea dos resíduos. A idade média das pacientes foi de $39,7 \pm 7,1$ anos. A maioria era caucasiana (64,5\%), apresentava ensino superior completo (56,5\%), e era nuligesta (40,3\%). Infertilidade estava presente em $48,4 \%$ das pacientes estudadas. Do total de casos $80,6 \%$ eram sintomáticas e queixaram-se principalmente de dor acíclica, 79\%de dismenorreia , e $61,3 \%$ de dispareunia em , refletindo a influência negativa da endometriose sobre a qualidade de vida das pacientes portadores desta doença.

Conclusão Dispareunia e dor acíclica foram fatores independentes de correlação com altos escores no EHP-30, refletindo uma pior qualidade de vida.

\section{Introduction}

Endometriosis is a chronic disease that is defined as the presence of endometrium-like tissue (glands and/or stroma) outside the uterine cavity that affects young, sexually active women of childbearing age. ${ }^{1}$

The most commonly reported complaint by patients is pain that can be expressed in a variety of symptoms, including dysmenorrhea, dyspareunia, chronic pelvic pain, and infertility. These symptoms affect social, emotional and physical well-being. The quality of life and relationships of the patients are significantly affected by the presence of dyspareunia. ${ }^{2-5}$

According to the main international guidelines, endometriosis should be seen as a disease that requires an individualized planning for life, and repetitive surgical procedures should be avoided. ${ }^{6}$ Its definitive diagnosis is surgical, and the gold standard is laparoscopy with confirmation through the anatomic-pathological study of the lesion. However, suspicion and clinical diagnosis are starting points to reduce the delay between the onset of symptoms and the recognition of the disease, ${ }^{7-9}$ since a delay of up to 9 years is reported prior to the definitive diagnosis. ${ }^{10,11}$

Knowing that one of the most common locations of endometriosis is ovarian, transvaginal ultrasonography (TVUSG) emerges as the most accessible imaging method to diagnose pelvic endometriosis, and is still the preferred method to differentiate endometriomas from other ovarian cysts. $^{12}$
It is estimated that the current prevalence of endometriosis is $\sim$ between 6 and $10 \%$ in the general population, but this number is still uncertain. About 17 to $44 \%$ of these patients also present endometriomas that are defined as ovarian pseudocysts due to the growth of ectopic endometrial tissue, which progressively invaginates the ovarian cortex. ${ }^{13-16}$

Assessments of the real impact of pelvic pain on the mental health and on the health-related quality of life of women have not yet yielded conclusive results. ${ }^{17}$ Several questionnaires aim to evaluate the quality of life of patients with endometriosis, but until recently, the most used are generic instruments that do not accurately reflect the reality of this specific type of patient, because they do not collect information on all of the areas of well-being that may be relevant to women with endometriosis. Two endometriosisspecific questionnaires have been developed and used in previous researches, but the validity of these instruments is questionable, given that most of the items were derived by clinicians and/or were scales taken from generic healthstatus questionnaires. ${ }^{18,19}$

In 2001, Jones et $\mathrm{al}^{20}$ developed an endometriosis-specific questionnaire entitled Endometriosis Health Profile - 30 (EHP-30). This questionnaire differs from others because it is a patient-generated instrument, in which all of the participants included had surgically-confirmed endometriosis and were symptomatic at the time of diagnosis. They performed psychometric tests using the 87 items of the questionnaire to identify the most salient dimensions of endometriosis that affect the quality of life of each patient. 
The EHP-30 has been extensively tested and validated in different cultural environments in the American, Australian, Dutch, Italian, Chinese, Iranian, Portugal and Brazilian Portuguese versions. ${ }^{20-26}$ The use of these questionnaires allows for more complete assessments, and they are also important in evaluating the perception of women of disease impact and treatment effectiveness in clinical scenarios.

Studies that used both specific or generic questionnaires showed a lower quality of life in patients with endometriosis. However, they did not distinguish peculiar (e.g., clinical, epidemiological) characteristics that could be associated with worse scores. These prior works have also not approached the specific subgroup with ovarian endometriosis who we hypothesized may have a different perception of pain due to the anatomical distortion of the pelvis caused by the endometrioma. With this in mind, the present study aimed to evaluate the existence of an association between ultrasound findings and epidemiological and clinical factors using results obtained from the EHP-30 questionnaire in women with ovarian endometriosis.

\section{Methods}

A cross-sectional observational study was performed and was approved by the Brazilian research ethics committee. It included the patients of the Endometriosis and Chronic Pelvic Pain Outpatient Clinic of the Hospital do Servidor Público Estadual Francisco Morato de Oliveira, São Paulo, state of São Paulo, Brazil, between July 2012 and May 2015. The sample size was calculated using the Open Source Epidemiologic Statistics for Public Health (OpenEpi) software. Since the prevalence of ovarian endometriosis varies between 17 and $44 \%$ of patients with endometriosis, up to 65 cases would be necessary to obtain a $95 \%$ confidence level. ${ }^{27}$

The participants were recruited until we reached the sample size calculation. A total of 65 sexually active Brazilian women of reproductive age with pelvic pain presenting transvaginal ultrasound imaging suggestive of ovarian endometriotic cysts, which were later confirmed by laparoscopy, were included. The patients had no other chronic pathology justifying the pain symptoms, had not started any treatment, and also agreed to participate in the research and signed the informed consent form after being briefed on the details of the study by a physician. The participants were assured that their data would remain confidential and that they could withdraw their consent at any time. Three patients were excluded because they had no histological diagnosis of the disease. In the first evaluation, we collected data regarding age, race, schooling, number of pregnancies, and symptoms such as dysmenorrhea and dyspareunia. Afterwards, the patients self-completed the standard EHP-30 questionnaire in its validated Brazilian Portuguese version in a private office to access the baseline quality of life scores, in order to better understand the real impact of the disease without any interference of previous therapeutic approaches.

The EHP-30 is a self-reporting tool developed from interviews to assess health-related quality of life that is specifically designed for patients with endometriosis. It consists of a central questionnaire composed of 30 items that assess 5 dimensions (i.e., pain, control and impotence, emotional well-being, social support, and self-image), and a modular questionnaire composed of 23 items distributed into 6 sections. The modular questionnaire sought to assess the impact of the disease in the following six domains: work (Section A), relationship with children (Section B), sexual relations (Section C), relationship with physician (Section D), treatment (Section E), and infertility (Section F). These scales are transformed into a score from 0 to 100 , in which 0 indicates a better health status, while 100 indicates a worse quality of life.

The data collected was plotted using Microsoft Excel for Windows (Microsoft Corp., Redmond, WA, USA). The Statistical analysis was performed through IBM SPSS Statistics for Windows, Version 22.0 (IBM Corp., Armonk, NY, USA) to provide a descriptive analysis and a comparison of the data through linear multiple regression analysis to highlight potential correlations between the epidemiological factors and symptoms and the questionnaire scores. Linear multiple regression modeling was performed using the stepwise forward technique to fit the best model. Statistical significance was attributed when $p<0.05$, with a confidence interval (CI) of $95 \%$.

\section{Results}

The data collection process of the study is shown in - Fig. 1 . The epidemiological characteristics of the sample studied were as follows: the mean age of the 62 patients was $39.7 \pm 7.1$ years old (with a minimum age of 20 and a maximum of 54 years old). The majority was Caucasian (64.5\%), had a high level of schooling with complete higher education (56.5\%), and was nulligravida (40.3\%). Of these, $48.4 \%$ of the patients studied were infertile.

Regarding the symptoms, the patients reported acyclic pain (80.6\%), dysmenorrhea (79\%), and dyspareunia (61.3\%); $21 \%$ had bilateral ovarian cysts (i.e., endometriomas), with a mean cyst size of $37 \mathrm{~mm}$ (10-95 $\mathrm{mm})$. For the evaluation of the averages, of the standard deviations (SDs), and of the minimum and maximum scores in the central and modular questionnaires of the EHP-30, the scales were transformed into a scoring system that ranged from 0 to 100 (-Table 1).

The completion rate of all items in the central questionnaire was 100\% (62/62). Regarding the modular questionnaire, considering that not all dimensions are applicable to all patients, the filling rate ranged from 56.45\% (35/62) in Section B to $96.77 \%$ (60/62) in Section D. For the multiple statistical analyses, the distribution of the outcome variable (i.e., the dependent variable) was confirmed as a normal distribution. A univariate analysis was performed between the outcome variable and the clinical and epidemiological factors, and a linear multiple regression was conducted (-Table $\mathbf{2}$ ).

In the multiple analyses for the general questionnaire score, we observed that dyspareunia and acyclic pain were independent correlation factors for a higher total EHP-30 score adjusted for dysmenorrhea, cyst bilateralism, and larger cyst diameter. The suitability of the linear regression model was confirmed by 


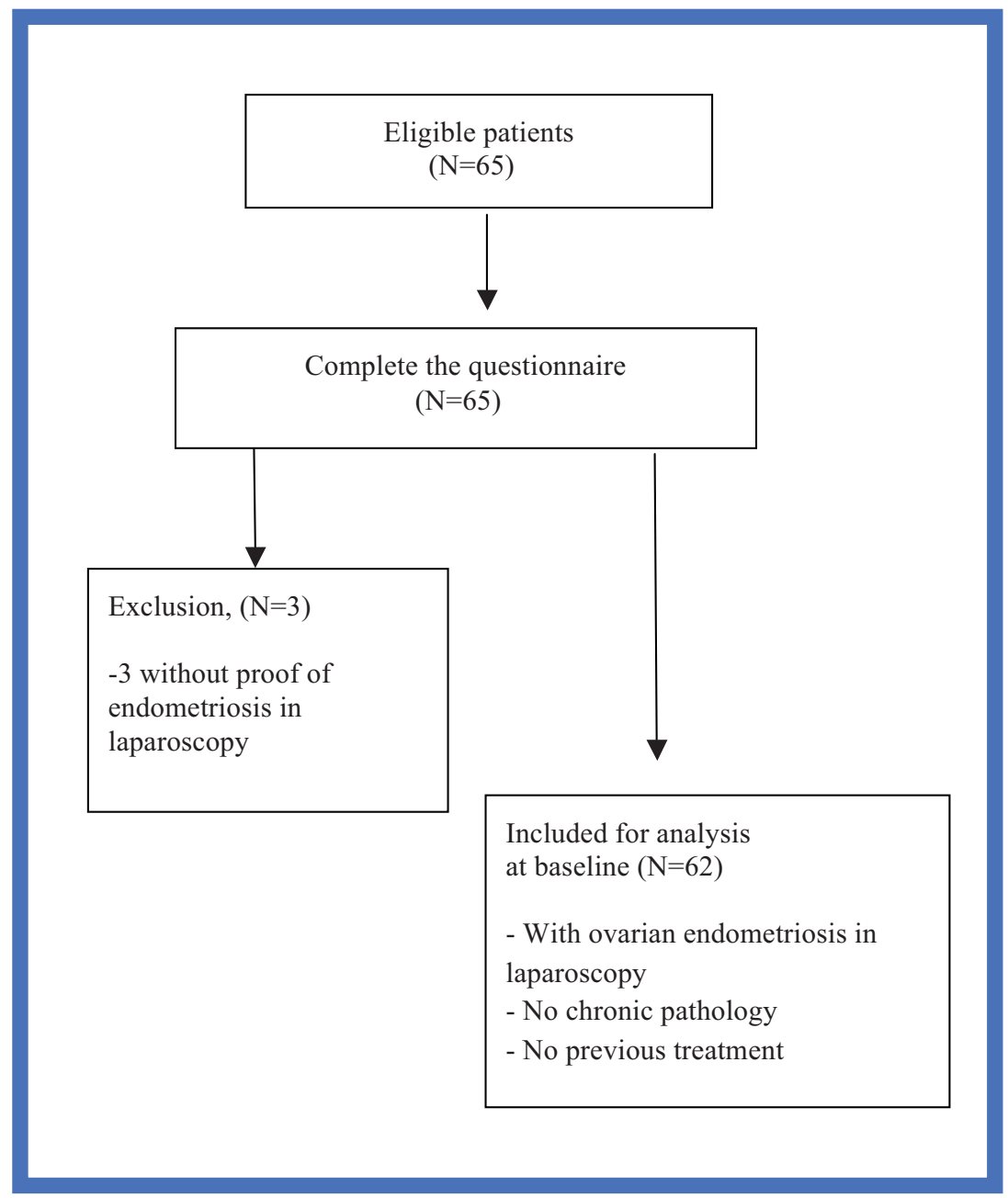

Fig. 1 Flowchart of the recruitment process of the patients.

the residue distribution graph, which confirmed the trend of linearity as well as the homogeneous dispersion of residues. When we applied the statistical model to the modular questionnaire, in Section A, no variable was significantly correlated with an increase in the score. When applied to Section B, the variables age and Caucasian women were presented as independent correlation factors with higher scores, and age was inversely correlated with score, while Caucasian women had direct correlation and were adjusted by the variables dyspareunia and acyclic pelvic pain ( - Table 3 ).

When Section C was evaluated, the only variable that presented a positive correlation with score in this section was dyspareunia $(p=0.015)$, adjusted for abortion, parity, acyclic pain, and greater cyst diameter. In Sections $D$ and $E$, all variables in the final statistical model, even after being adjusted, did not present a significant correlation with the EHP-30 scores. Conversely, in Section F, it was observed that dysmenorrhea and dyspareunia were associated with higher scores in this section ( - Table 4$)$.

\section{Discussion}

Endometriosis can occur in any woman who menstruates, and a higher risk has been found in women aged between 35 and
44 years old.$^{28}$ The mean age of the patients in our study was $39.7 \pm 7.1$ years old, corresponding to the age range in which endometriosis is usually diagnosed. Complaints of acyclic pain (80.6\%), of dysmenorrhea (79\%), of dyspareunia (61.3\%), and of infertility (48.4\%) were slightly higher than those found by Bellelis et al (2010), showing a profile of clinical-epidemiological characteristics among population samples. ${ }^{29}$

In the present study, the EHP-30 questionnaire was applied to evaluate the quality of life of patients with endometriosis. It is important to mention that a cutoff point for the scores obtained in this questionnaire has not yet been established in the literature, and this makes it difficult to fully understand impairments in quality of life. Therefore, comparisons were made to correlate linearity through the regression analysis.

Compared with the data presented in the other studies that validated the EHP-30 in several countries, in the modular questionnaire, we obtained the highest mean scores related to impact on work, sexual intercourse, and relationship with children, and the lowest mean scores regarding infertility.

After a multiple linear regression analysis, -Table 2 shows that dyspareunia and acyclic pain presented as independent factors of positive correlation with the total score of the EHP-30 questionnaire, and that the high prevalence of 
552 Quality of Life Assessment by the Endometriosis Health Profile (EHP-30) Questionnaire Florentino et al.

Table 1 Trend measures and descriptive statistics of the central and modular EHP-30 questionnaires

\begin{tabular}{|l|l|l|l|l|}
\hline Variables of EHP-30 & Average & Standard deviation & Minimum grade & Maximum grade \\
\hline $\begin{array}{l}\text { Central questionnaire }(n=62) \\
\text { Modular questionnaire }\end{array}$ & 61.61 & 18.37 & 20 & 95.33 \\
\hline $\begin{array}{l}\text { Section A } \\
\text { Work } \\
(n=54)\end{array}$ & 54.49 & 22.72 & 20 & 92 \\
\hline $\begin{array}{l}\text { Section B } \\
\text { Relationship with children } \\
(n=35)\end{array}$ & 50.28 & 25.26 & 20 & 100 \\
\hline $\begin{array}{l}\text { Section C } \\
\text { Sexual Relations } \\
(n=55)\end{array}$ & 66.98 & 22.77 & 20 & 100 \\
\hline $\begin{array}{l}\text { Section D } \\
\text { Relationship with physician } \\
(n=60)\end{array}$ & 37.58 & 20.65 & 20 & 90 \\
\hline $\begin{array}{l}\text { Section E } \\
\text { Treatment } \\
(n=42)\end{array}$ & 50 & 21.75 & 20 & 93.33 \\
\hline $\begin{array}{l}\text { Section F } \\
\text { Infertility } \\
(n=39)\end{array}$ & 51.07 & 24.21 & 16 & 100 \\
\hline Total score & 55.52 & 15.85 & 19.53 & 83.59 \\
\hline
\end{tabular}

Table 2 Linear multiple regression for the analysis of clinical and ultrasound factors correlated with the weighted overall EHP-30 score $(n=62)$

\begin{tabular}{|l|l|l|}
\hline $\begin{array}{l}\text { Analyzed } \\
\text { variable }\end{array}$ & $\begin{array}{l}\text { Unadjusted analysis } \\
\text {-value }(\mathrm{CI})\end{array}$ & $\begin{array}{l}\text { Final adjusted model } \\
p \text {-value }(\mathrm{CI})\end{array}$ \\
\hline Dyspareunia & $0.000(9.18-23.56)$ & $0.001(5.72-19.84)$ \\
\hline Acyclic pain & $0.001(7.09-25.82)$ & $0.001(6.37-22.78)$ \\
\hline Dysmenorrhea & $0.032(0.93-20.13)$ & $0.131(-1.95-14.70)$ \\
\hline Bilateralism & $0.159(-2.81-16.81)$ & $0.229(-3.15-12.89)$ \\
\hline $\begin{array}{l}\text { Larger cyst } \\
\text { diameter }\end{array}$ & $0.177(-0.72-0.38)$ & $0.725(-0.15-0.22)$ \\
\hline
\end{tabular}

Abbreviation: $\mathrm{Cl}$, confidence interval.

Table 3 Linear multiple regression for the analysis of clinical and ultrasound factors correlated with weighted scores for EHP-30 Section B (children) $(n=35)$

\begin{tabular}{|l|l|l|}
\hline $\begin{array}{l}\text { Analyzed } \\
\text { variable }\end{array}$ & $\begin{array}{l}\text { Unadjusted analysis } \\
\text { p-value }(\mathrm{Cl})\end{array}$ & $\begin{array}{l}\text { Final adjusted model } \\
\text { p-value }(\mathrm{Cl})\end{array}$ \\
\hline Age & $0.002(-3.04--0.72)$ & $0.020(-2.71--0.24)$ \\
\hline Caucasian & $0.014(5.02-40.57)$ & $0.036(1.35-37.64)$ \\
\hline Dyspareunia & $0.023(2.90-36.14)$ & $0.249(-6.75-25.04)$ \\
\hline Acyclic pain & $0.051(-0.09-47.43)$ & $0.501(-15.13-30.26)$ \\
\hline
\end{tabular}

Abbreviation: $\mathrm{Cl}$, confidence interval.

these symptoms significantly interferes with the personal and sexual lives of the patients, which may reflect a greater negative impact on their quality of life. This finding is corroborated by de Freitas Fonseca et al. ${ }^{30}$

Lukic et $\mathrm{al}^{31}$ studied women with pelvic endometriosis and found that the symptom perceived as being most responsible
Table 4 Linear multiple regression for the analysis of clinical and ultrasound factors correlated with weighted scores for EHP30 Section $\mathrm{F}$ (infertility) $(n=39)$

\begin{tabular}{|l|l|l|}
\hline $\begin{array}{l}\text { Analyzed } \\
\text { variable }\end{array}$ & $\begin{array}{l}\text { Unadjusted analysis } \\
p \text {-value }(\mathrm{Cl})\end{array}$ & $\begin{array}{l}\text { Final adjusted model } \\
p \text {-value }(\mathrm{CI})\end{array}$ \\
\hline Dysmenorrhea & $0.022(4.33-53.02)$ & $0.007(8.69-50.29)$ \\
\hline Dyspareunia & $0.046(0.32-32.25)$ & $0.022(2.74-33.18)$ \\
\hline Age & $0.156(-1.61-0.27)$ & $0.153(-1.58-0.26)$ \\
\hline Abortion & $\begin{array}{l}0.717 \\
(-16.49-11.47)\end{array}$ & $\begin{array}{l}0.686 \\
(-16.26-10.82)\end{array}$ \\
\hline
\end{tabular}

Abbreviation: $\mathrm{Cl}$, confidence interval.

for the deterioration of quality of life for women with endometriosis is dyspareunia. They also found that, after surgery, these women experienced a significant decrease in this symptom. In the specific group of patients with ovarian endometriosis, we believe that pain may also be due to the anatomical distortion that endometriomas create in the pelvis, which does not respond completely to conservative treatment, thus indicating that the localization of endometriotic foci are responsible for the intensity of the pain symptoms.

In the present study, a higher score is observed in the modular questionnaire in Section C, which evaluates the effects of endometriosis on sexual relations. The mean score was $66.98 \pm 22.77$ (20-100), and this trend measure could also potentially interfere with the prevalence of the dyspareunia symptom found in the studied population (61.3\%). Previous studies have also shown that women with endometriosis and dyspareunia experience worse sexual function than women 
without endometriosis. ${ }^{32-34}$ We know that endometriosis affects young and sexually active women; therefore, sexual health should be a primary concern in the clinical management of this disease. This negative impact between endometriosis, pain and sexual function have also been confirmed by Vercellini et al. $^{35}$

Another relevant finding of our study was the association of dysmenorrhea and dyspareunia with high scores on the question of infertility. This association largely reiterates the negative influence of pain on the general quality of life and sexual satisfaction that, in turn, interferes with the reproduction of patients with endometriosis. It is well-established in the literature that chronic pelvic pain and the experience of pain during intercourse affects negatively the lives of the patients. ${ }^{36}$ Authors have also shown that endometriosis affects negatively several aspects of the quality of life of women - both physically and mentally. ${ }^{10,37}$

In addition, we found a correlation between a worse quality of life and the relationship with children and Caucasian women, but this fact may be only associated with the higher prevalence of Caucasians in our study. Soliman et al also found a higher prevalence of white patients with endometriosis in their case studies. ${ }^{38}$

One of the most difficult moments in the management of ovarian endometriosis is deciding when to opt for surgical treatment, because it is known that patients have had both pain and endometrioma recurrence even after laparoscopy. ${ }^{39}$ Because the treatment for endometriosis aims to improve the quality of life, we believe that a perspective for further studies with this specific subgroup of endometriosis patients could explore the prognostic value of the EHP-30 to define a cutoff point in which the patient with endometrioma would benefit more from surgical or clinical treatment. This could potentially guide gynecologists and surgeons in carefully tailoring their strategies to each individual case. Currently, the EHP-30 has not been greatly applied in the clinical practice of gynecologists, neither in studies evaluating quality of life in patients with endometriosis. ${ }^{20}$

The strengths of the present study include the fact that we have only selected women with ovarian endometriosis who also had not begun any treatment before answering the questionnaire. This enabled us to understand the real impact of the disease without any influences. To our knowledge, this is the first Brazilian study that has tried to correlate clinical and epidemiological factors with quality of life scores using a disease-specific questionnaire in women presenting with ovarian endometriosis.

The limitations of the present study were derived from the study design, from the small sample size, and from the fact that we have only evaluated women at baseline. Results after surgical intervention were not yet analyzed, which could limit the interpretation and the external validity of the results of the present study. However, we have already developed a research line to continue the longitudinal investigation with a larger sample to compare quality of life before and after treatment. These results might help to better understand the effects of therapeutic interventions on the quality of life of these patients.

\section{Conclusion}

The results of the present study showed an association between dyspareunia and acyclic pain, exerting a negative influence on the overall EHP-30 score at baseline prior to any treatment. This reflects a worse quality of life among patients with ovarian endometriosis who present those clinical factors. Also, it reinforces that endometriosis affects several areas in the lives of women and that improved general well-being should be the main goal of gynecologists.

\section{Contributors}

Florentino A. V. A. , Pereira A. M. G., Martins J. A., Lopes R. G. C., and Arruda R. M. contributed with the project and interpretation of data, the writing of the article, the critical review of the intellectual content, and with the final approval of the version to be published.

\section{Conflicts of Interests}

The authors have no conflicts of interests to declare.

\section{References}

1 Abrão MS, Petraglia F, Falcone T, Keckstein J, Osuga Y, Chapron C. Deep endometriosis infiltrating the recto-sigmoid: critical factors to consider before management. Hum Reprod Update 2015;21 (03):329-339. Doi: 10.1093/humupd/dmv003

2 Kennedy S, Bergqvist A, Chapron C, et al; ESHRE Special Interest Group for Endometriosis and Endometrium Guideline Development Group. ESHRE guideline for the diagnosis and treatment of endometriosis. Hum Reprod 2005;20(10):2698-2704. Doi: 10.1093/humrep/ dei135

3 Moradi M, Parker M, Sneddon A, Lopez V, Ellwood D. Impact of endometriosis on women's lives: a qualitative study. BMC Womens Health 2014;14:123. Doi: 10.1186/1472-6874-14-123

4 Denny E, Mann $\mathrm{CH}$. Endometriosis-associated dyspareunia: the impact on women's lives. J Fam Plann Reprod Health Care 2007; 33(03):189-193. Doi: 10.1783/147118907781004831

5 Ferrero S, Esposito F, Abbamonte LH, Anserini P, Remorgida V, Ragni N. Quality of sex life in women with endometriosis and deep dyspareunia. Fertil Steril 2005;83(03):573-579. Doi: 10.1016/j.fertnstert.2004.07.973

6 Practice Committee of the American Society for Reproductive Medicine. Treatment of pelvic pain associated with endometriosis: a committee opinion. Fertil Steril 2014;101(04):927-935. Doi: 10.1016/j.fertnstert.2014.02.012

7 Dunselman GA, Vermeulen N, Becker C, et al; European Society of Human Reproduction and Embryology. ESHRE guideline: management of women with endometriosis. Hum Reprod 2014;29 (03):400-412. Doi: 10.1093/humrep/det457

8 Jacobson TZ, Duffy JMN, Barlow D, Koninckx PR, Garry R. Laparoscopic surgery for pelvic pain associated with endometriosis. Cochrane Database Syst Rev 2009;(04):CD001300. Doi: 10.1002/ 14651858.CD001300.pub2

9 Arruda MS, Petta CA, Abrão MS, Benetti-Pinto CL. Time elapsed from onset of symptoms to diagnosis of endometriosis in a cohort study of Brazilian women. Hum Reprod 2003;18(04):756-759. Doi: 10.1093/humrep/deg136

10 Nnoaham KE, Hummelshoj L, Webster P, et al; World Endometriosis Research Foundation Global Study of Women's Health consortium. Impact of endometriosis on quality of life and work productivity: a multicenter study across ten countries. Fertil Steril 2011;96(02): 366-373.e8. Doi: 10.1016/j.fertnstert.2011.05.090 
11 Culley L, Law C, Hudson N, et al. The social and psychological impact of endometriosis on women's lives: a critical narrative review. Hum Reprod Update 2013;19(06):625-639. Doi: 10.1093/ humupd/dmt027

12 Mais V, Guerriero S, Ajossa S, Angiolucci M, Paoletti AM, Melis GB. The efficiency of transvaginal ultrasonography in the diagnosis of endometrioma. Fertil Steril 1993;60(05):776-780. Doi: 10.1016/ S0015-0282(16)56275-X

13 Burney RO, Giudice LC. Pathogenesis and pathophysiology of endometriosis. Fertil Steril 2012;98(03):511-519. Doi: 10.1016/j. fertnstert.2012.06.029

14 TanboT, Fedorcsak P. Endometriosis-associated infertility: aspects of pathophysiological mechanisms and treatment options. Acta Obstet Gynecol Scand 2017;96(06):659-667. Doi: 10.1111/aogs.13082

15 Gruppo Italiano per lo Studio Dell'Endometriosi. Prevalence and anatomical distribution of endometriosis in women with selected gynaecological conditions: results from a multicentric Italian study. Gruppo italiano per lo studio dell'endometriosi. Hum Reprod 1994; 9(06):1158-1162. Doi: 10.1093/oxfordjournals.humrep.a138650

16 Jenkins S, Olive DL, Haney AF. Endometriosis: pathogenetic implications of the anatomic distribution. Obstet Gynecol 1986; 67(03):335-338

17 Eriksen HL, Gunnersen KF, Sørensen JA, Munk T, Nielsen T, Knudsen UB. Psychological aspects of endometriosis: differences between patients with or without pain on four psychological variables. Eur J Obstet Gynecol Reprod Biol 2008;139(01): 100-105. Doi: 10.1016/j.ejogrb.2007.10.002

18 Bodner CH, Garratt AM, Ratcliffe J, Macdonald LM, Penney GC. Measuring health-related quality of life outcomes in women with endometriosis-results of the Gynaecology Audit Project in Scotland. Health Bull (Edinb) 1997;55(02):109-117

19 Colwell HH, Mathias SD, Pasta DJ, Henning JM, Steege JF. A healthrelated quality-of-life instrument for symptomatic patients with endometriosis: a validation study. Am J Obstet Gynecol 1998;179 (01):47-55. Doi: 10.1016/S0002-9378(98)70250-9

20 Jones G, Kennedy S, Barnard A, Wong J, Jenkinson C. Development of an endometriosis quality-of-life instrument: The Endometriosis Health Profile-30. Obstet Gynecol 2001;98(02):258-264. Doi: 10.1016/S0029-7844(01)01433-8

21 Khong SY, Lam A, Luscombe G. Is the 30-item Endometriosis Health Profile (EHP-30) suitable as a self-report health status instrument for clinical trials? Fertil Steril 2010;94(05):1928-1932. Doi: 10.1016/j. fertnstert.2010.01.047

22 Jenkinson C, Kennedy S, Jones G. Evaluation of the American version of the 30-item Endometriosis Health Profile (EHP-30). Qual Life Res 2008;17(09):1147-1152. Doi: 10.1007/s11136-008-9403-9

23 van de Burgt TJM, Hendriks JCM, Kluivers KB. Quality of life in endometriosis: evaluation of the Dutch-version Endometriosis Health Profile-30 (EHP-30). Fertil Steril 2011;95(05):1863-1865. Doi: $10.1016 /$ j.fertnstert.2010.11.009

24 Nojomi M, Bijari B, Akhbari R, Kashanian M. The assessment of reliability and validity of Persian version of the endometriosis health profile (EHP-30). Iran J Med Sci 2011;36(02):84-89

25 Nogueira-Silva C, Costa P, Martins C, et al. Validation of the Portuguese Version of EHP-30 (The Endometriosis Health Profile-30). Acta Med Port 2015;28(03):347-356

26 Mengarda CV, Passos EP, Picon P, Costa AF, Picon PD. [Validation of Brazilian Portuguese version of quality of life questionnaire for women with endometriosis (Endometriosis Health Profile Questionnaire-EHP-30)]. Rev Bras Ginecol Obstet 2008;30(08): 384-392. Doi: 10.1590/S0100-72032008000800003

27 Mereu L, Florio P, Carri G, Pontis A, Petraglia F, Mencaglia L. Clinical outcomes associated with surgical treatment of endometrioma coupled with resection of the posterior broad ligament. Int J Gynaecol Obstet 2012;116(01):57-60. Doi: 10.1016/j.jigo.2011.08.017

28 Abbas S, Ihle P, Köster I, Schubert I. Prevalence and incidence of diagnosed endometriosis and risk of endometriosis in patients with endometriosis-related symptoms: findings from a statutory health insurance-based cohort in Germany. Eur J Obstet Gynecol Reprod Biol 2012;160(01):79-83. Doi: 10.1016/j.ejogrb.2011.09.041

29 Bellelis P, Dias JA Jr, Podgaec S, Gonzales M, Baracat EC, Abrão MS Epidemiological and clinical aspects of pelvic endometriosis-a case series. Rev Assoc Med Bras (1992) 2010;56(04):467-471. Doi: 10.1590/S0104-42302010000400022

30 de Freitas Fonseca M, Aragao LC, Sessa FV, Dutra de Resende JA Jr, Crispi CP. Interrelationships among endometriosis-related pain symptoms and their effects on health-related quality of life: a sectional observational study. Obstet Gynecol Sci 2018;61(05): 605-614. Doi: 10.5468/ogs.2018.61.5.605

31 Lukic A, Di Properzio M, De Carlo S, et al. Quality of sex life in endometriosis patients with deep dyspareunia before and after laparoscopic treatment. Arch Gynecol Obstet 2016;293(03): 583-590. Doi: 10.1007/s00404-015-3832-9

32 Ferrero S, Abbamonte LH, Giordano M, Ragni N, Remorgida V. Deep dyspareunia and sex life after laparoscopic excision of endometriosis. Hum Reprod 2007;22(04):1142-1148. Doi: 10.1093/humrep/del465

33 Fritzer N, Haas D, Oppelt P, et al. More than just bad sex: sexual dysfunction and distress in patients with endometriosis. Eur J Obstet Gynecol Reprod Biol 2013;169(02):392-396. Doi: 10.1016/j.ejogrb.2013.04.001

34 Shum LK, Bedaiwy MA, Allaire C, et al. Deep dyspareunia and sexual quality of life in women with endometriosis. Sex Med 2018;6(03):224-233. Doi: 10.1016/j.esxm.2018.04.006

35 Vercellini P, Somigliana E, Buggio L, Barbara G, Frattaruolo MP, Fedele L. "I can't get no satisfaction": deep dyspareunia and sexual functioning in women with rectovaginal endometriosis. Fertil Steril 2012;98(06):1503-11.e1. Doi: 10.1016/j. fertnstert.2012.07.1129

36 De Graaff AA, D'Hooghe TM, Dunselman GA, Dirksen CD, Hummelshoj L, Simoens S; WERF EndoCost Consortium. The significant effect of endometriosis on physical, mental and social wellbeing: results from an international cross-sectional survey. Hum Reprod 2013;28(10):2677-2685. Doi: 10.1093/humrep/det284

37 Chaman-ara K, Bahrami MA, Moosazadeh M, Bahrami E. Quality of life in women with endometriosis: a systematic review and metaanalysis. WCRJ 2017;4:e839

38 Soliman AM, Coyne KS, Zaiser E, Castelli-Haley J, Fuldeore MJ. The burden of endometriosis symptoms on health-related quality of life in women in the United States: a cross-sectional study.J Psychosom Obstet Gynaecol 2017;38(04):238-248. Doi: 10.1080/0167482X. 2017.1289512

39 Porpora MG, Pallante D, Ferro A, Crisafi B, Bellati F, Benedetti Panici P. Pain and ovarian endometrioma recurrence after laparoscopic treatment of endometriosis: a long-term prospective study. Fertil Steril 2010;93(03):716-721. Doi: 10.1016/j.fertnstert.2008.10.018 